\title{
LAYANAN INFORMASI UPAYA MENINGKATKAN KEDISIPLINAN MENGHADAPI PRAKTIK KERJA INDUSTRI DI SEKOLAH MENENGAH KEJURUAN
}

\author{
MAE ENDANG IRIASTUTI \\ SMK Negeri 1 Kalasan, Sleman, DIY \\ maeprambanan@gmail.com
}

\begin{abstract}
ABSTRAK
Tujuan pendidikan kejuruan adalah menyiapkan peserta didik untuk memasuki dunia kerja, dunia usaha serta mengembangkan sikap professional. Untuk menyiapkan sumber daya yang berkualitas tersebut pemerintah membuat kebijakan penyelenggaraan Pendidikan Sisten Ganda (PSG). Dalam rangka pelaksanaan Pendidikan Sisten Ganda, program praktik kerja industri merupakan program wajib yang harus dilaksanakan di sekolah kejuruan. Agar supaya praktik kerja industri dapat tercapai dengan maksimal, maka peserta didik perlu diberikan layanan informasi tentang data dan fakta serta gambaran pelaksanaan praktik kerja industri melalui layanan informasi oleh guru Bimbingan Konseling. Literature review bertujuan untuk mengumpulkan dan menganalisa serta mencari kesamaam pandangan tentang manfaat dan pengaruh layanan informasi terhadap kedisiplinan peserta didik.. Desain Literature review menggunakan artikel dan jurnal yang terbit tahun 2017 sd 2020. Dari lima artikel dan jurnal terpilih yang telah dianalisa, didapat kesamaan hasil bahwa, layanan informasi secara efektif berpengaruh terhadap pemahaman dan kepercayaan diri, prestasi, kematangan karir, serta kedisiplinan peserta didik.
\end{abstract}

Kata Kunci : Layanan Informasi, Disiplin Peserta Didik, Praktik Kerja Industri

\section{PENDAHULUAN.}

Sekolah Menengah Kejuruan (SMK) merupakan salah satu bentuk satuan pendidikan formal yang menyelenggarakan pendidikan kejuruan pada jenjang pendidikan menengah dengan tujuan untuk menghasilkan manusia yang produktif, dan manusia kerja bukan manusia beban keluarga, masyarakat dan bangsanya (Soenaryo,et al 2002 dalam Suwarman). Kurikulum Sekolah Menengah Kejuruan dibuat untuk mempersiapkan peserta didik langsung kedunia kerja. Maka dari itu, muatan kurikulum Sekolah Menengah disusun sedemikian rupa segingga dapat memenuhi kebutuhan dunia kerja dan dunia usaha. Dengan demikian, maka peserta didik tidak mengalami kesulitan dalam menentukan karir ketika lulus nantinya. Beberapa upaya guna meningkatkan kualitas pendidikan dan mutu kompetensi SMK agar lulusannya dapat terserap dan sesuai dengan kebutuhan tuntutan dunia kerja, Kementerian Pendidikan Nasional membuat suatu program yang dapat mensinkronkan antara SMK dengan dunia kerja dan dunia industri dengan menggunakan model pendidikan kejuruan yang dikenal dengan Pendidikan Sistem Ganda (PSG).

Pendidikan Sistem Ganda sebagai salah satu implementasi dari kebijakan link and match yang dicetuskan pertama kali oleh Prof. Dr. Ing Wardiman Djojonegoro. Link and match adalah kebijakan Departemen Pendidikan dan Kebudayaan yang dikembangkan untuk mengimplikasikan wawasan sumber daya, mutu, keunggulan, profesionalisme dan meningkatkan relevansi SMK dengan kebutuhan dunia kerja melalui tingkat pemenuhan tenaga kerja dan pemenuhan permintaan di dunia usaha serta dunia industri.

Dalam rangka pelaksanaan program Pendidikan Sistem Ganda tersebut salah satu kegiatan yang wajib dilaksanakan oleh sekolah adalah praktik kerja industri (Prakerin). Praktik Kerja Industri bertujuan untuk memadukan teori pembelajaran dengan kondisi lapangan untuk mendapatkan pengalaman, menumbuhkan rasa percaya diri, melatih keterampilan untuk menunjang skill (Yanto,2006) Dengan pelaksanaan praktik kerja industri diharapkan peserta didik dapat menguasai kompetensi yang benar dan terstandar, mempunyai sikap dan etos kerja 
sesuai dengan persyaratan tenaga kerja professional yang sesuai dengan Undang-undang praktik kerja industri yang berlaku. Terdapat tiga indikator keberhasilan praktik kerja industri : 1) Aspek personal yaitu sikap, perilaku dan kedisiplinan 2) Aspek pengetahuan dan keterampilan, 3) Aspek social atau hubungan dengan lingkungan sekitar (Aisatun Nifah, 2015)

Menurut Elly (2016) disiplin merupakan sikap dan perilaku yang menunjukkan kesediaan untuk mematuhi ketentuan, peraturan, tata tertib serta nilai dan kaidah yang berlaku. Johan (2014) mengatakan bahwa disiplin bagi peserta didik adalah sesuatu yang rumit dipelajari karena merupakan hal yang komplek berkaitan dengan pengetahuan, sikap dan perilaku. Menurut Ahmad Rohani (2004) disiplin mencakup setiap macam pengaruh yang ditunjukkan untuk membantu peserta didik agar dapat memahami dan menyesuaikan diri dengan tuntunan yang mungkin ingin ditujukan peserta didik terhadap lingkungannya.

Dari beberapa pendapat tersebut, dapat dikatakan bahwa disiplin mengandung asas kesediaan untuk mematuhi ketentuan peraturan, tata tertib serta nilai dan kaidah yang berlaku dengan berpengetahuan, bersikap, berperilaku dan bertindak secara konsisten guna menyesuaikan diri dengan tuntutan dilingkungannya. Hal tersebut dapat dicapai dengan pemberikan layanan informasi oleh guru Bimbingan Konseling. Di Sekolah, kedisiplinan sangat penting digunakan untuk mengontrol tingkah laku peserta didik agar sesuai dengan peraturan dan tata tertib yang berlaku, sehingga kegiatan belajar mengajar akan berlangsung dengan efektif dan nyaman, sekolah dapat menjadi kondusif, termasuk di dalamnya kegiatan praktik kerja industri dapat berjalan maksimal untuk mencapai tujuan.

Agar supaya praktik kerja industri dapat berhasil dan mencapai tujuan yang maksimal, salah satu upaya dengan meningkatkan kedisiplinan peserta didik. Untuk meningkatkan kedisiplinan, guru Bimbingan Konseling memberikan layanan informasi sesuai dengan kebutuhan peserta didik. Peranan guru Bimbingan Konseling sangatlah diperlukan bagi peserta didik dalam membatu peningkatan perkembangannya. Prayitno dan Amti (2004:259) berpendapat bahwa layanan informasi adalah kegiatan memberikan pemahaman kepada individu yang berkepentingan tentang berbagai hal yang diperlukan untuk menjalani suatu tugas atau kegiatan untuk menentukan arah suatu tujuan atau rencana yang dikehendaki. Menurut Sukardi (2000:21), layanan Informasi adalah suatu proses untuk membantu pribadi peserta didik dalam mengembangkan penerimaan kesatuan informasi atau gambaran dirinya serta peranannya dalam dunia kerja. Menurut Winkel dalam Tohirin (2014:142) menyatakan bahwa layanan informasi nerupakan suatu layanan yang berupaya memenuhi kekurangan individu akan informasi yang mereka perlukan. Deni Siregar (2012) pengertian layanan informasi adalah suatu upaya yang dilakukan dalam memberikan berbagai informasi kepada peserta didik kaitannya dengan pengembangan dirinya agar memperoleh pandangan yang lebih luas.

Dari beberapa uraian diatas, dapat dipahami bahwa dengan layanan informasi peserta didik akan dapat mengembangkan pemahaman, penerimaan diri, memenuhi kekurangan informasi, memperoleh pengetahuan, memperoleh pandangan dan gambaran yang lebih luas untuk menentukan arah tujuan yang dikehendaki. Berdasarkan penjelasan di atas bahwa layanan informasi pada peserta didik dapat menjadi solusi atau gambaran dan wawasan dalam memecahkan masalah kedisiplinan. Layanan informasi yang diperlukan peserta didik sebelum mengikuti praktik kerja industri adalah layanan informasi tentang data dan fakta serta gambaran pelaksanaan praktik kerja industri agar supaya peserta didik dapat melaksanakan praktik kerja industri sesuai dengan peraturan dan ketentuan yang berlaku.

\section{METODE PENELITIAN}

Desain Penelitian ini menggunakan Literature Review. Menurut Snyder (2019:333) mengatakan bahwa Literature Review adalah sebuah metodologi penelitian yang bertujuan untuk mengumpulkan dan mengambil intisari dari penelitian sebelumnya serta menganalisa beberapa overview para ahli yang tertulis dalam teks. Yang dimaksud dengan Literature Review bukan hanya sekedar membaca literature, tetapi lebih kearah analisis dan evalusi yang mendalam dan kritis tentang penelitian sebelumnya pada suatu topik tertentu. 
Intervensi utama yang ditelaah pada Literature Review ini adalah layanan informasi untuk meningkatkan kedisiplinan dalam menghadapi praktik kerja industri siswa Sekolah Menengan Kejuruan. Penelusuran pencarian literature dengan cara searching pada google search, google shoolar atau google cendekia dengan menggunakan kata kunci. Literatur yang dipilih menggunakan artikel dan jurnal yang terbit kurun waktu empat tahun terakir yaitu tahun 2017 sd 2020 yang dapat diakses fulltext-pdf dengan Bahasa Indonesia. Artikel dan jurnal yang sesuai dengan kriteria inkluasi dan eksklusi diambil untuk selanjutnya dianalisis dan dievaluasi dengan mengurai kalimat kemudian dicari persamaan dan perbedaan pada masing-masing aktikel dan jurnal kemudian dibahas untuk dibuat sebuah simpulan. Kriteria inklusi literature review dapat dilihat pada tabel berikut

Tabel 1 . Kriteria Inklusi Penelitian

\begin{tabular}{|l|l|}
\hline \multicolumn{1}{|c|}{ Kriteria } & \multicolumn{1}{c|}{ Inklusi } \\
\hline Jangka Waktu & $\begin{array}{l}\text { Penerbitan artikel dan jurnal kurun waktu empat tahun } \\
\text { terakhir antara tahun 2017 sd 2020 }\end{array}$ \\
\hline Subjek & Layanan Informasi. \\
\hline Bahasa & Bahasa Indonesia \\
\hline Jenis Jurnal & Artikel dan jurnal penelitian, full text pdf \\
\hline Tema & $\begin{array}{l}\text { Layanan Informasi Upaya Meningkatkan Kedisiplinan } \\
\text { Menghadapi Praktik Kerja Industri. }\end{array}$ \\
\hline
\end{tabular}

Berdasarkan hasil penelusuran Google Scoolar dan Google Search dengan kata kunci Layanan Informasi, Disiplin peserta didik dan Praktik Kerja Industri, ditemukan 254 artikel dan jurnal yang sesuai dengan kata kunci tersebut. Sebanyak 81 artikel dan jurnal tersebut dilakukan skrining, 51 artikel dan jurnal diekskluasi karena tidak tersedia artikel dan jurnal full text. Assesment kelayakan terhadap 30 artikel dan jurnal full text dilakukan, jurnal yang duplikasi dan tidak sesuai kriteria inklusi dilakukan eksklusi sebanyak 25, sehingga 5 artikel dan jurnal full text yang dilakukan review.

Gambar 1. Diagram Alur Review Artikel dan Jurnal

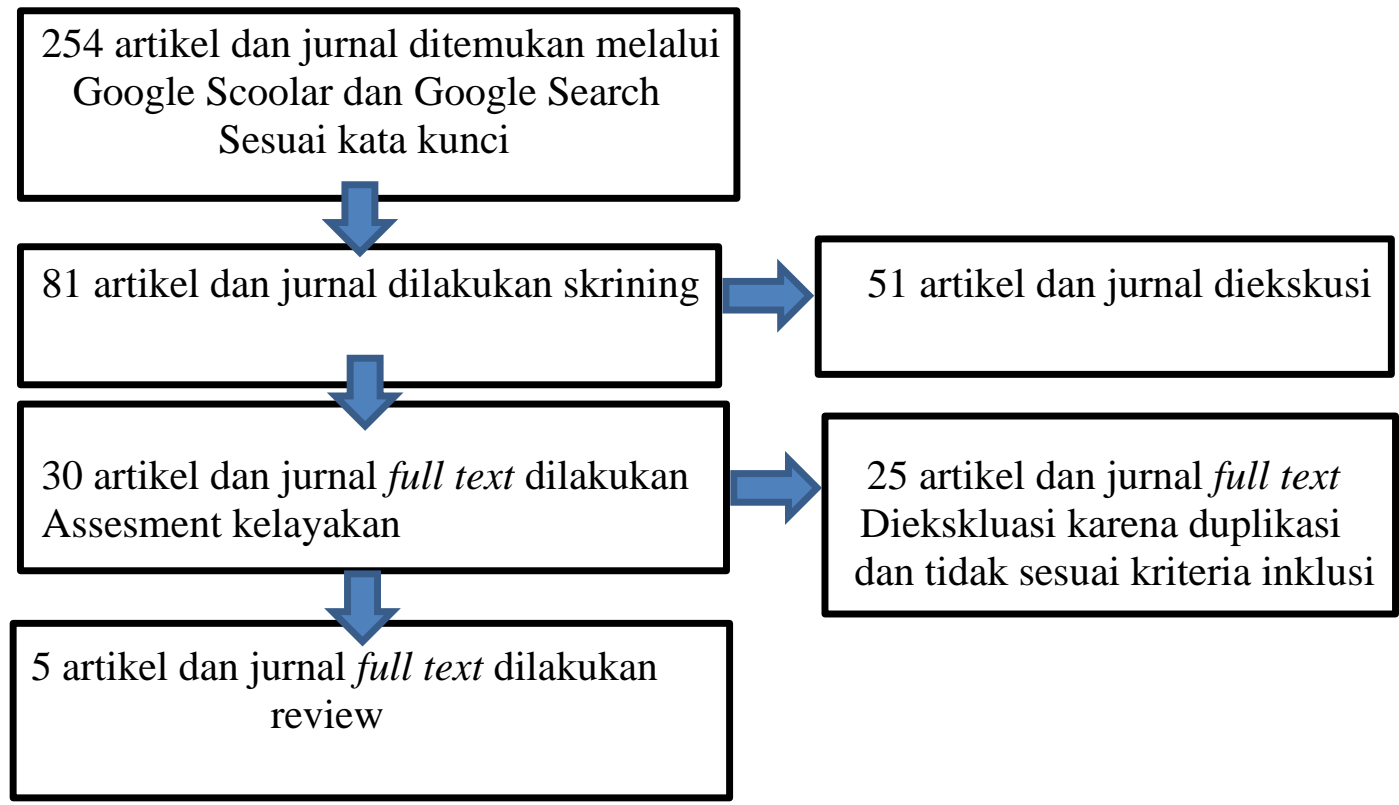

\section{HASIL DAN PEMBAHASAN}

Berdasarkan alur Review Artikel dan Jurnal yang telah dilakukan, maka didapatkan 5 (lima) artikel dan jurnal yang akan dianalisis dan dicari perbedaan dan persamaannya untuk dibuat sebuah simpulan. Dari hasil Literature Review ini diharapkan dapat memecahkan 
masalah tentang kedisiplinan peserta didik dalam menghadapi Praktik Kerja Industri di Sekolah Menengah Kejuruan.

Tabel 2. Tabel Literature Review

\begin{tabular}{|c|c|c|}
\hline No & Judul & Hasil dan Uraian \\
\hline 1 & $\begin{array}{l}\text { Pengaruh layanan } \\
\text { informasi berbasis } \\
\text { media audio visual } \\
\text { terhadap } \\
\text { pemahaman karier } \\
\text { siswa XI MIA 2MA } \\
\text { Darul Ulum Waru } \\
\text { Sidoarjo. } \\
\text { Oleh : Afridatus } \\
\text { Solikhah dan } \\
\text { Moesarofah } \\
\text { Tahun } 2020 \text {. }\end{array}$ & $\begin{array}{l}\text { Penelitian } 1 \text { bertujuan untuk mengetahui } \\
\text { seberapa efektif layanan informasi berbasis media } \\
\text { audio visual terhadap pemahaman karir siswa } \\
\text { Madrasah Aliyah. Jenis penelitian pra } \\
\text { eksperiment dengan rancangan one group pre-test } \\
\text { post-test. Populasinya adalah siswa MA X Sidoarjo } \\
\text { kelas XI MIA } 2 \text { sejumlah } 38 \text { siswa. Pengambilan } \\
\text { sampel dengan tehnik purposive random sampling. } \\
\text { Pengambilan data menggunakan angket dan } \\
\text { interview. Instrumen yang digunakan adalah lembar } \\
\text { observasi, lember interview dan angket } \\
\text { Dalam membuat keputusan karir, siswa } \\
\text { membutuhkan pemahaman yang matang. Jika } \\
\text { pemahaman tentang karir tersebut masih kurang } \\
\text { maka siswa belum memahami potensi dirinya, } \\
\text { menjadi kurang tanggung jawab, dan akan } \\
\text { terhambat dalam pengembangan karirnya. Dalam } \\
\text { penelitian artikel } 1 \text { ini, terdapat perbedaan yang } \\
\text { signifikan pemahaman karir siswa antara sebelum } \\
\text { dan sesudah diberi treatment. } \\
\text { Hasil penelitian ini menunjukkan bahwa } \\
\text { layanan informasi media audio visual secara efektif } \\
\text { berpengaruh terhadap peningkatan pemahaman } \\
\text { karir siswa, membekali siswa dengan pengetahuan } \\
\text { sehingga dalam pengambilan keputusan karir, dapat } \\
\text { sesuai dengan potensi dirinya. }\end{array}$ \\
\hline 2 & $\begin{array}{l}\text { Layanan Informasi } \\
\text { melalui Media } \\
\text { Animasi Untuk } \\
\text { Meningkatkan } \\
\text { Kematangan Karir } \\
\text { Peserta Didik. } \\
\text { Oleh : Nazulla } \\
\text { Niftyra Nindya at.al } \\
\text { Tahun } 2019\end{array}$ & $\begin{array}{l}\text { Tujuan penelitian } 2 \text { untuk mendiskripsikan } \\
\text { pelaksanaan layanan informasi media animasi untuk } \\
\text { meningkatkan kematangan karir peserta didik kelas } \\
\text { XII MIPA3 SMA Negeri1 Karang anyar Demak } \\
\text { Tahun pelajaran 2018/2019 dengan tujuan untuk } \\
\text { memperbaiki mutu layanan Bimbingan Konseling } \\
\text { agar sistematis dan rasional. Jenisnya Penelitian } \\
\text { Tindakan Bimbingan Konseling . Populasi } \\
\text { penelitian adalah Siswa kelas XII MIPA } 3 \text { SMA } \\
\text { Negeri } 1 \text { Karanganyar Demak. } \\
\text { Kematangan karir menjadi salah satu dasar } \\
\text { akan kehidupan masa depan. Peserta didik yang } \\
\text { memiliki konsep perencanaan karir, memiliki } \\
\text { motivasi tinggi untuk meraih cita-cita. Layanan } \\
\text { informasi melalui media animasi dapat menambah } \\
\text { wawasan, mempermudah dalam pengambilan } \\
\text { keputusan dan memilih keputusan terhadap rencana } \\
\text { karirnya. }\end{array}$ \\
\hline
\end{tabular}




\begin{tabular}{|c|c|c|}
\hline & & $\begin{array}{l}\text { Hasil penelitian menunjukkan } \\
\text { pelaksanaan layanan informasi melalui media } \\
\text { animasi dapat diterapkan dalam peningkatan } \\
\text { kematangan karir peserta didik karena adanya } \\
\text { peningkatan. Setelah mendapatkan treatment. } \\
\text { Hipotesis diterima karena sudah memenuhi } \\
\text { indikator keberhasilan. }\end{array}$ \\
\hline 3 & $\begin{array}{l}\text { Hubungan antara } \\
\text { Intensitas Layanan } \\
\text { Informasi dengan } \\
\text { kedisiplinan belajar } \\
\text { siswa kelas XI. LI } \\
\text { SMK Saraswati } \\
\text { Salatiga. } \\
\text { Oleh : Khori } \\
\text { Wahyu, et.al, Tahun } \\
\text { 2019. }\end{array}$ & $\begin{array}{l}\text { Kedisiplinan dalam proses pendidikan sangat } \\
\text { diperlukan untuk menjaga situasi dan kondisi } \\
\text { pembelajaran berjalan dengan lancar. Untuk } \\
\text { menumbuhkan sikap disiplin diperlukan salah satu } \\
\text { layanan bimbingan konseling yaitu layanan } \\
\text { informasi. } \\
\text { Penelitian ini bertujuan mengetahui hubungan } \\
\text { yang signifikan antara intensitas layanan informasi } \\
\text { dengan kedisiplinan belajar siswa kelas XI. LI SMK } \\
\text { Saraswati Karanganyar. Metode yang digunakan } \\
\text { metode kuantitatif dengan jenis deskriptif } \\
\text { korelasional. Dengan skala likert. Populasi yang } \\
\text { diambil Siswa kelas XI LI. SMK Saraswati Salatiga } \\
\text { berjumlah 90 siswa. Tehnik pengambilan sampel } \\
\text { menggunakan tehnik total sampling. Alat ukur } \\
\text { dengan skala layanan informasi (teori depdiknas } \\
\text { 2007) dan skala kedisiplinan (teori Tu'u 2004). } \\
\text { Hasil penelitian } 3 \text { menunjukkan bahwa terdapat } \\
\text { hubungan yang signifikan antara intensitas layanan } \\
\text { informasi dengan kedisiplinan belajar siswa kelas } \\
\text { XI. LI SMK Saraswati Salatiga }\end{array}$ \\
\hline 4 & $\begin{array}{l}\text { Keefektifan } \\
\text { Layanan Informasi } \\
\text { berbasis Instagram } \\
\text { untuk meningkatkan } \\
\text { kepercayaan diri } \\
\text { siswa. } \\
\text { Oleh : Akhmad } \\
\text { Rifqi Azis \& Prili } \\
\text { Aprilia } \\
\text { Tahun } 2018\end{array}$ & $\begin{array}{l}\text { Tujuan penelitian ke } 4 \text { untuk melihat apakah } \\
\text { terdapat peningkatan kepercayaan diri siswa setelah } \\
\text { mendapatkan layana informasi berbasis isntagram. } \\
\text { Desain penelitian menggunakan one-group pre-test } \\
\text { and post-test design. Tehnik pengambilan data } \\
\text { dengan angket dan dokumentasi. Populasi } \\
\text { penelitian seluruh Siswa SMK Negeri } 1 \text { Arjasa yang } \\
\text { berjumlah } 136 \text { siswa. } \\
\text { Salah satu dampak pengguna Instagram adalah } \\
\text { krisis percaya diri, persaingan kehidupan mewah, } \\
\text { dan kurang melihat realita. Mudah mengikuti trend } \\
\text { yang sedang berlangsung dikalangan mereka untuk } \\
\text { mencari kepopuleran. Pada penelitian ini mengukur } \\
\text { apakah layanan informasi efektif untuk } \\
\text { meningkatkan kepercayaan diri peserta didik? } \\
\text { Hasil dari penelitian } 4 \text { menunjukkan bahwa } \\
\text { layanan informsi berbasis Instagram efektif untuk } \\
\text { meningkatkan kepercayaan diri siswa yaitu terjadi } \\
\text { perubahan perilaku, pola pikir, komunikasi, } \\
\text { ketegasan, penampilan, pengandalian perasaan, }\end{array}$ \\
\hline
\end{tabular}




\begin{tabular}{|l|l|l|}
\hline & & $\begin{array}{l}\text { memahami diri sehingga peserta didik dapat } \\
\text { mempunyai tujuan yang jelas. }\end{array}$ \\
\hline 5 & $\begin{array}{l}\text { Kontribusi layanan } \\
\text { informasi dalam } \\
\text { konseling dan } \\
\text { kedisiplinan siswa } \\
\text { terhadap prestasi } \\
\text { belajar siswa. }\end{array}$ & $\begin{array}{l}\text { Penelitian ke 5 untuk mengetahui pengaruh } \\
\text { layanan informasi dan kedisiplinan siswa terhadap } \\
\text { prestasi belajar siswa, pengaruh layanan informasi } \\
\text { terhadap prestasi belajar siswa, pengaruh } \\
\text { kedisiplinan siswa terhadap prestasi belajar siswa. } \\
\text { Oleh : Sri Utami. } \\
\text { Tahun 2017 }\end{array}$ \\
$\begin{array}{l}\text { Termasuk jenis penelitian kuantitatif dengan tehnk } \\
\text { regresi. Populasi penelitian siswa SMK Kota } \\
\text { Depok, dengan Populasi jumlah 824 siswa, dan } \\
\text { sampel 80 siswa, diambil secara proporsional } \\
\text { random sampling. } \\
\text { Prestasi belajar merupakan salah satu tolok } \\
\text { ukur keberhasilan pembelajaran. Prestasi belajar } \\
\text { dipengaruhi oleh bebetapa factor, baik dari dalam } \\
\text { maupun dari luar. Layanan informasi sebagai salah } \\
\text { satu layanan dalam bimbingan konseling sebagai } \\
\text { wahana bagi guru Bimbingan Konseling dalam } \\
\text { membantu peningkatan prestasi belajar peserta } \\
\text { didik. } \\
\text { Hasil dari penelitian 5 menunjukkan bahwa terdapat } \\
\text { pengaruh yang signifikan layanan informasi dan } \\
\text { kedisiplinan terhadap prestasi belajar terdapat } \\
\text { pengaruh yang signifikan layanan informasi } \\
\text { terhadap prestasi belajar terdapat pengaruh yang } \\
\text { signifikan kedisiplinan terhadap prestasi belajar } \\
\text { Siswa. }\end{array}$ \\
\hline
\end{tabular}

Persamaan yang dapat ditemukan dari literature review terhadap kelima artikel dan jurnal tersebut adalah instrument yang digunakan dalam penelitian tersebut menggunakan angket, observasi, wawancara dan dokumen. Jenis penelitian termasuk penelitian kuantitatif yaitu penelitian ilmiah yang sistematis terhadap bagian-bagian dan fenomena serta kausalitas hubungan. Kelima penelitian tersebut menunjukkan hasil yang positif dan signifikan, yaitu 1).layanan informasi berbasis media audio visual secara efektif berpengaruh terhadap peningkatan pemahaman karir siswa, 2). Setelah mendapatkan layanan informasi melalui media animasi, siswa lebih memahami dan meningkatnya kematangan karir, 3). terdapat hubungan yang signifikan antara intensitas layanan informasi dengan kedisiplinan belajar siswa, 4). layanan informasi berbasis Instagram efektif untuk meningkatkan kepercayaan diri siswa, 5). terdapat pengaruh yang signifikan antara layanan informasi terhadap prestasi belajar, antara kedisiplinan terhadap prestasi belajar dan layanan informasi dan kedisiplinan bersama-sama terhadat prestasi belajar.

Dari uraian hasil kelima artikel dan jornal diatas terdapat perbedaan terutama pada metode yang digunakan. Penelitian, 1 dan 4 menggunakan metode eksperimen yang bertujuan untuk menyelidiki adanya kemungkinan hubungan sebab akibat dengan cara melakukan control atau kendali. Penelitian 2 menggunakan metode tindakan untuk mengembangkan keterampilan baru atau pendekatan baru yang diterapkan langsung kemudian dikaji hasilnya untuk memperbaiki layanan bimbingan konseling. Penelitian 3 dengan korelasional, untuk mengkaji tingkat keterkaitan antara variasi suatu factor dengan variasi factor lain berdasarkan koefisien korelasi. Penelitian 5 menggunakan metode diskripsi yang menggambarkan secara fakta dan karakteristik objek yang diteliti secara tepat. Subjek dalam penelitian 1,2,3 dan 5 adalah peserta didik SMA/MA dan SMK (Sekolah Lanjutan Tingkat Atas), sedangkan penelitian 4 menggunakan subjek peserta didik SMP (Sekolah Lanjutan Tingkat Pertama). 
Dari hasil analisis ke lima artikel dan jurnal di atas, dengan persamaan hasil bahwa Layanan informasi berbasis media audio visual, berbasis media animasi maupun berbasis Instagram secara efektif berpengaruh terhadap peningkatan pemahaman dan kematangan karir, peningkatan kepercayaan diri, peningkatan prestasi belajar serta peningkatan kedisiplinan peserta didik. Berbagai layanan informasi yang diselenggarakan di sekolah untuk membekali peserta didik dengan berbagai pengetahuan tentang lingkungan yang diperlukan untuk memecahkan masalah yang dihadapi berkenaan dengan lingkungan sekitar, pendidikan, jabatan, maupun social budaya. Dengan demikian layanan informasi merupakan kebutuhan yang amat tinggi tingkatannya.

Perilaku ketidak disiplinan yang timbul disebabkan oleh sikap yang dimiliki oleh setiap siswa (Soekidjo Notoatmodjo. 2003). Pada dasarnya sikap yang dimiliki oleh setiap siswa sudah ada, namun sikap tersebut masih lemah sehingga antara sikap dan perilaku yang muncul sering kali tidak konsisten. Berdasarkan hal tersebut maka guru Bimbingan Konseling berupaya meningkatkan kedisiplinan peserta didik dengan memberikan layanan informasi secara terencana, terprogram dan berkesinambungan yang menggunakan berbagai metode dan berbagai macam informasi yang disesuaikan dengan kebutuhan peserta didik.

\section{KESIMPULAN.}

Berdasarkan hasil ke lima literature review dari artikel dan jurnal diatas adalah bahwa layanan informasi sebagai layanan bimbingan konseling yang dilaksanakan secara terencana , terprogram dan berkesinambungan yang mempunyai andil besar dalam mengakomodir kebutuhan peserta didik akan informasi-informasi yang dibutuhkan. Dari pernyataan tersebut dapat disimpulkan bahwa peserta didik yang mendapatkan layanan informasi yang sesuai dengan kebutuhan dan berkelanjutan akan berpengaruh secara efektif terhadap peningkatan pemahaman dan kematangan karir, peningkatan kepercayaan diri, peningkatan prestasi belajar, peningkatan pengetahuan dan perilaku, serta kedisiplinannya akan lebih baik dibanding dengan peserta didik yang kurang mendapat layanan informasi.

\section{DAFTAR PUSTAKA}

Afridatus Solihah, Moesarofah, (2020) Pengaruh Layanan Informasi Berbasis Media Audio Visual Terhadap Pemahaman Karir Siswa XI MIA SMA Darul Ulum Wuru Sidoarja, Universitas PGRI Adi Buana Surabaya, https://doi.org/10.1234/pdabkin.v1i1.30

Aisatun Nifah, (2015) Pengaruh Pengalaman Praktik Kerja Industri, Efikasi Diri, Dan Kompetensi Akuntansi Terhadap Kesiapan Kerja Siswa Kelas XII Program Keahlian Akuntansi Di SMK PGRI 2 Kota Salatiga Tahun Ajaran 2014/2015, Skripsi, Universitas Negeri Semarang

Akhmad Rifqi \& Prili Aprilia, (2018) Kefektifan Layanan Informasi Berbasis Instagram untuk Meningkatkan Kepercayaan Diri Siswa, IKIP PGRI Jember, e-journal BK, ISSN 25802054, DOI: $10.26539 / 1363$

Budi Tri Siswanto, (2011) "Pendidikan Vokasi, Work-Based Learning, dan Penyelenggaraan Program Praktik Pengalaman Lapangan, Skripsi Fakultas Teknik Universitas Muhammadiyah Magelang.

Deni Siregar (2012), Pemberian Layanan Informasi Untuk Meningkatkan Kedisiplinan Siswa Di MA NW Wanasaba, STKIP Hamzanwadi Selong, http://ejournal.hamzanwadi.ac.id/index.php/edc/article/view/123

Elly, Rosma (2016) Hubungan Kedisiplinan terhadap Hasil Belajar Siswa Kelas V SD Negeri 10 Banda Aceh. E-Journal Pesona Dasar Vol. 3 No. 4 Hal. 43-53, http://www.jurnal.unsyiah.ac.id/index/search/categories.

Johan, Ria Susanti (2014) Peran Motivasi dan Disiplin dalam Menunjang Prestasi Belajar Peserta Didik pada Bidang Studi IPS. E-Journal Ilmiah Kependidikan Vol. 1 No. 3 Hal. 275-286. https://journal.lppmunindra.ac.id/index.php/Faktor/article/view/364 
Khoiri at.al, (2019) Hubungan antara Intensitas Layanan Informasi Dengan Kedisiplinan Belajar Siswa Kelas XI LI SMK Saraswati Salatiga, FKIP-Universitas Kristen Satya Wacana, e-journal Genta Mulia, ISSN 2301-6671.

https://ejournal.stkipbbm.ac.id/index.php/gm/article/view/342/295

Nuzulla at.al ,(2019) Layanan Informasi Melalui Media Animasi Untuk Meningkatkan Kematangan Karir Peserta Didik, Jurnal Prakarsa Paedagogia, Vol 2 No.2 Hal 133-140, ISSN 2620-9780, https://jurnal.umk.ac.id/index.php/JKP/article/view/4504

Prayitno \& Amti. (2004). Dasar Bimbingan dan Konseling. Jakarta: Rineka Cipta

Snyder, H.(2019) 'Literature review as a research methodology: An overview and guidelines'. E-Journal of Business Research, 104, pp. 333-339

Soekidjo Atmodjo, (2003) Pendidikan Dan Perilaku Kesehatan,Jakarta,Rineka Cipta.

Sri Utami, (2017) Kontribusi Layanan Informasi dalam Konseling dan Kedisiplinan Siswa Terhadap Prestasi Belajar Siswa, Universitas Indraprasta PGRI Jakarta, e-journal ISSN 2580-2054.

Sukardi, D. K, (2000) Pengantar Pelaksanaan Program Bimbingan dan Konseling. Jakarta: RinekaCipta,http://kin.perpusnas.go.id/DisplayData.aspx?pId=95264\&pRegionCode= UN11MAR\&pClientId $=112$

Suwarman \& Pardjono, (2014) Pengelolaan Praktik Kerja Industri Pada Program Keahlian Teknik Pemesinan SMK Se-Kabupaten Kulon Progo, Universitas Negeri Yogyakarta, 2537-6878-1

Winkel dalam Tohirin,(2014 )Bimbingan dan Konseling di Sekolah dan Madrasah Jakarta:PT Raja Grafindo Persada, https://media/publications/215290.

Yanto, A. F. (2006) Ketidaksiapan Memasuki Dunia Kerja Karena Pendidikan. Jakarta: Dinamika Cipta. : https://doi.org/10.17509/jmee.v6i2.21789. 